\title{
Article
}

http://dx.doi.org/10.11646/phytotaxa.273.2.5

\section{A new species of Lepidaploa (Asteraceae: Vernonieae) from Minas Gerais State, Brazil}

DANILO MARQUES ${ }^{1} \&$ MASSIMILIANO DEMATTEIS $^{1}$

${ }^{1}$ Instituto de Botánica del Nordeste (UNNE-CONICET), Casilla de Correo 209, CP 3400 Corrientes, Argentina; email: danilobioufu@gmail.com

\begin{abstract}
Lepidaploa scintillans is described as a new species from the Minas Gerais State in southeastern Brazil. This new species can be easily distinguished from other Lepidaploa species by the sericeous, nacreous-argent indumentum of both leaf surfaces and by the subpaleaceous outer pappus, which are unusual features in this genus.
\end{abstract}

Key words: Compositae, Lepidaploinae, new taxon, taxonomy

\section{Introduction}

Vernonieae Cassini (1819: 203) contains 126 genera and approximately 1500 species, mostly in tropical parts of the world (Keeley \& Robinson 2009). Vernonieae has variable growth habits, ranging from small, scapose herbs to large trees (Bremer 1994). This variation led to the taxonomic history of the tribe to change over time, especially concerning the core genus Vernonia Schreber (1791: 541) (Robinson 1999, Keeley \& Robinson 2009).

A number of genera were segregated from Vernonia which now is a small genus mainly restricted to North America (Keeley \& Robinson 2009). The segregated genera include Lepidaploa Cassini (1817: 66) Cassini (1825: 20) and Lessingianthus Robinson (1988: 939), the largest genera of Vernonieae in the New World (Robinson 1999).

Lepidaploa was firstly described as a subgenus of Vernonia (Cassini 1817). Afterwards, Cassini (1825) considered Lepidaploa at the generic level. Candolle (1836) did not recognize Lepidaploa as a genus, placing it as section VIII of Vernonia. Baker (1873) maintained Lepidaploa as a section of Vernonia, including the majority of Brazilian species. Lastly, Robinson (1990) again raised Lepidaploa to the generic level, based on macromorphological, micromorphological, palynological and cytological features.

The genus Lepidaploa comprises about 150 species widely distributed in South America (Angulo et al. 2012). Lepidaploa is distinguished from the remaining American members of the tribe by the sessile heads, which have 1.3-3 times more involucral bracts than flowers, no glands on the anther appendages, nodular style bases, sometimes glanduliferous cypsela, cypsela wall with prismatic crystals, pollen type C, D or G, and basic chromosome number $x=$ 14, 15 or 16 (Robinson 1990, Keeley \& Robinson 2009, Marques \& Dematteis 2014, Via do Pico et al. 2016).

In this article we propose a new species of Lepidaploa from the Minas Gerais State, Brazil. This new species, $L$. scintillans, is illustrated and its affinities are discussed.

\section{Material and Methods}

\section{Description and illustration}

This study was based on macromorphology and micromorphology analysis of the type specimens deposited at MBM and CTES herbaria. The line drawings were done under camera lucida with a Leica MZ6 stereo microscope.

For micromorphological studies, floral parts were softened in boiling water and dissected under a stereo-microscope. 
Afterward, samples were mounted in Hoyer's solution (Anderson 1954, King \& Robinson 1970), and then examined with a Zeiss Axioplan.

\section{Palynological analysis}

Pollen samples were obtained by removing one or two florets from herbarium specimens and acetolyzed according to Erdtman (1966). For light microscopy (LM), pollen grains were mounted on glass slides using glycerine jelly and subsequently examined with a Zeiss Axioplan. This material was deposited at the collection of the Palynological Laboratory of the Universidad Nacional del Nordeste (PAL-CTES). The terminology applied for pollen grain description follows Erdtman (1966), Keeley \& Jones (1979), and Punt et al. (2007).

\section{Taxonomic treatment}

Lepidaploa scintillans Dematt. \& D. Marq., sp. nov. (Figs 1-4)

Erect shrub, ca. $1.5 \mathrm{~m}$ tall. Leaves spirally alternate, subsessile; blade lanceolate, coriaceous to chartaceous, discolor due to indumentum, margin entire, apex acute to acuminate, basally attenuate, both surface sericeous, nacreous, argent. Capitulescence seriate-cymose, short, recurved. Florets 10-12 per capitulum, corolla lilac, tube glabrescent, lobes lanceolate, sericeous, glandular, apex acuminate. Pappus biseriate, outer series subpaleaceous, inner series bristles.

Type:-BRAZIL. Minas Gerais: Nova Porteirinha, Torre da CEMIG, 14 April 2007, J.M. Silva \& O.S. Ribas 5655 (holotype: MBM!; isotype: CTES!).

Description:-Erect shrub, ca. $1.5 \mathrm{~m}$ tall, branched. Branches ca. $0.2 \mathrm{~cm}$ in diam., terete, striated, densely sericeous, white to grayish, leafy up to capitulescence, internodes $0.5-1.2 \mathrm{~cm}$ long. Leaves spirally alternate, simple, discolor due to indumentum, petiolate, ca. $0.3 \mathrm{~cm}$ long, coriaceous-chartaceous; blade 5.5-6.4 $\times 0.1-0.3 \mathrm{~cm}$, lanceolate, entire, apex acute to acuminate, base attenuate, both surfaces sericeous, nacreous, argent, pinnatinervate, veins prominent above, sericeous. Capitulescence 3.8-5.6 cm long, seriate-cymose, short, recurved, branches 4-6, short, with 6-7 capitula, leafy. Bracts of capitulescence leafy, 1-1.9 × 0.3-0.6 cm, lanceolate, sericeous. Involucre 6.4-7.7 mm long, homogamous, discoid, campanulate, peduncles $0.1-0.2 \mathrm{~cm}$ long; phyllaries 38-46 per capitulum, 6-8-seriate, sericeous, whitish; outer 2-3 $\times 0.5-0.8 \mathrm{~mm}$, lanceolate to linear-lanceolate, apex apiculate, margin serrulate; inner $6.2-6.5 \times 2-$ $2.1 \mathrm{~mm}$, elliptic-lanceolate, apex apiculate, margin serrulate. Florets 10-12, androgynous; corolla actinomorphic, lilac, tube 3.3-3.7 mm long, cylindrical, glabrescent, lobes $4.3-4.6 \mathrm{~mm}$ long, lanceolate, pilose, trichomes glandular and eglandular, apex acute; anthers 3.6-4.3 $\mathrm{mm}$ long, apical anther appendages acute, basal anther appendages caudate; styles 10.2-11 mm long, with hairs below bifurcation point of style arms; stylopodium cylindrical, brown. Cypselae $1.8-2.4 \mathrm{~cm}$ long, obconic, angled, sericeous, glandular, with idioblasts and prismatic crystals on wall; carpopodium annular; pappus biseriate, cream-coloured, outer series 0.9-1.1 mm long, subpaleaceous, inner series 4.4-5.5 mm long, bristles. Pollen grains (type G): prolate-spheroidal (P/E: $1.14 \mu \mathrm{m})$, triporate, echinolophate, polar axis 23.12 (23.8) $25.84 \mu \mathrm{m}$; equatorial diameter 19.04 (20.74) $23.12 \mu \mathrm{m}$. Pore lolongate, 6.8-8.16 $\times 5.44-6.8 \mu \mathrm{m}$. Exine, excluding spines, 4.08 (4.76) $5.44 \mu \mathrm{m}$. Tectum descontinuous, irregular caveate, surface microperfurate, spines 2.04 (2.55) 62.72 $\mu \mathrm{m}$ long.

Distribuition and ecology:-The new species occurs in Nova Porteirinha, Minas Gerais, Brazil. The analyzed material has been found in the Cerrado.

Phenology:-Flowers and fruits of this species were collected from April. However, flowering time might be extended to March and/or May.

Etymology:-The specific epithet refers to shimmering leaves of the species.

Discussion:-Lepidaploa scintillans is readily recognized by the sericeous, nacreous and argent indumentum of both leaf surfaces, and subpaleaceous outer pappus. The new taxon is a distinctive species because of the features mentioned above, but it can be confused with L. persericea Robinson (1990: 292) because of the indumentum type of the leaves. Morphological comparisons between L. scintillans and L. persericea are summarised in Table 1 . 


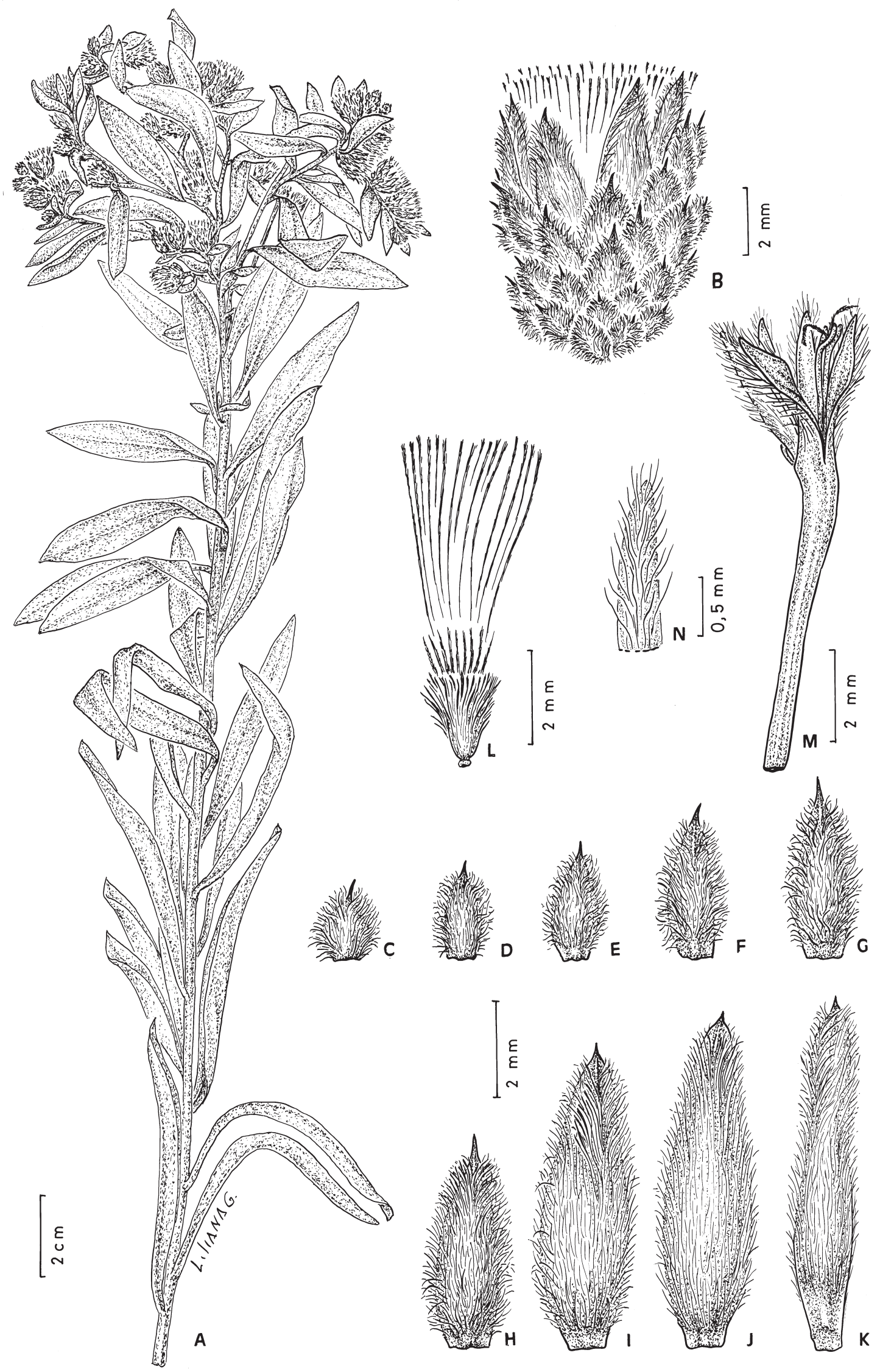

FIGURE 1. Lepidaploa scintillans (isotype). A: Plant. B: Capitulum. C-K: Phyllaries series. L: Cypsela with pappus. M: Floret. N: Detail of corolla lobes. (A-N: from J.M. Silva \& O.S. Ribas 5655, CTES; illustrated by Mirtha L. Gómez). 


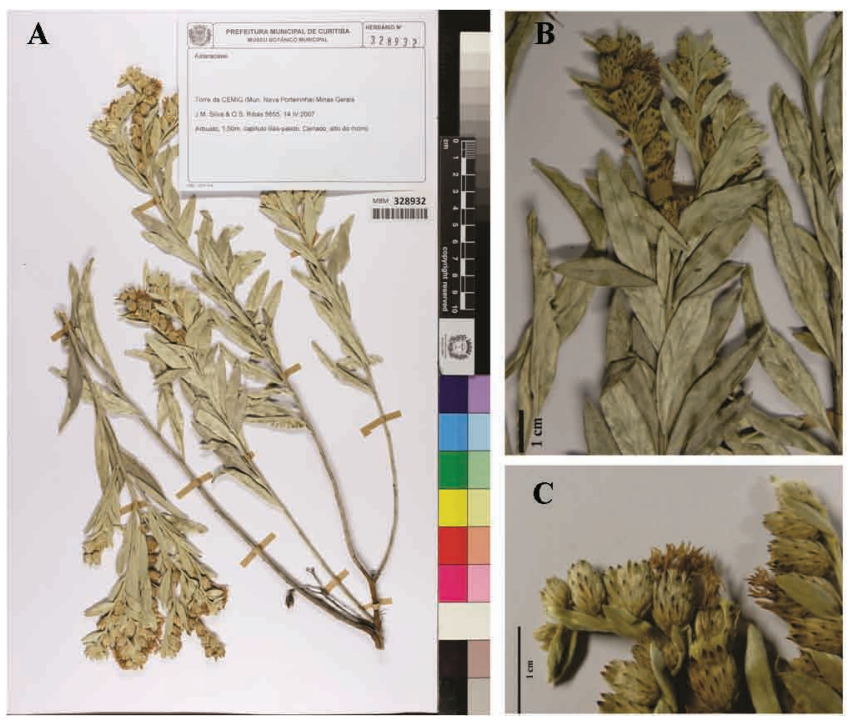

FIGURE 2. Lepidaploa scintillans details (holotype): A: Branch. B: Flowering branch showing the leaves. C: Capitula. (A-C: from J.M. Silva \& O.S. Ribas 5655, MBM; imaged by Eduardo D. Lozano).

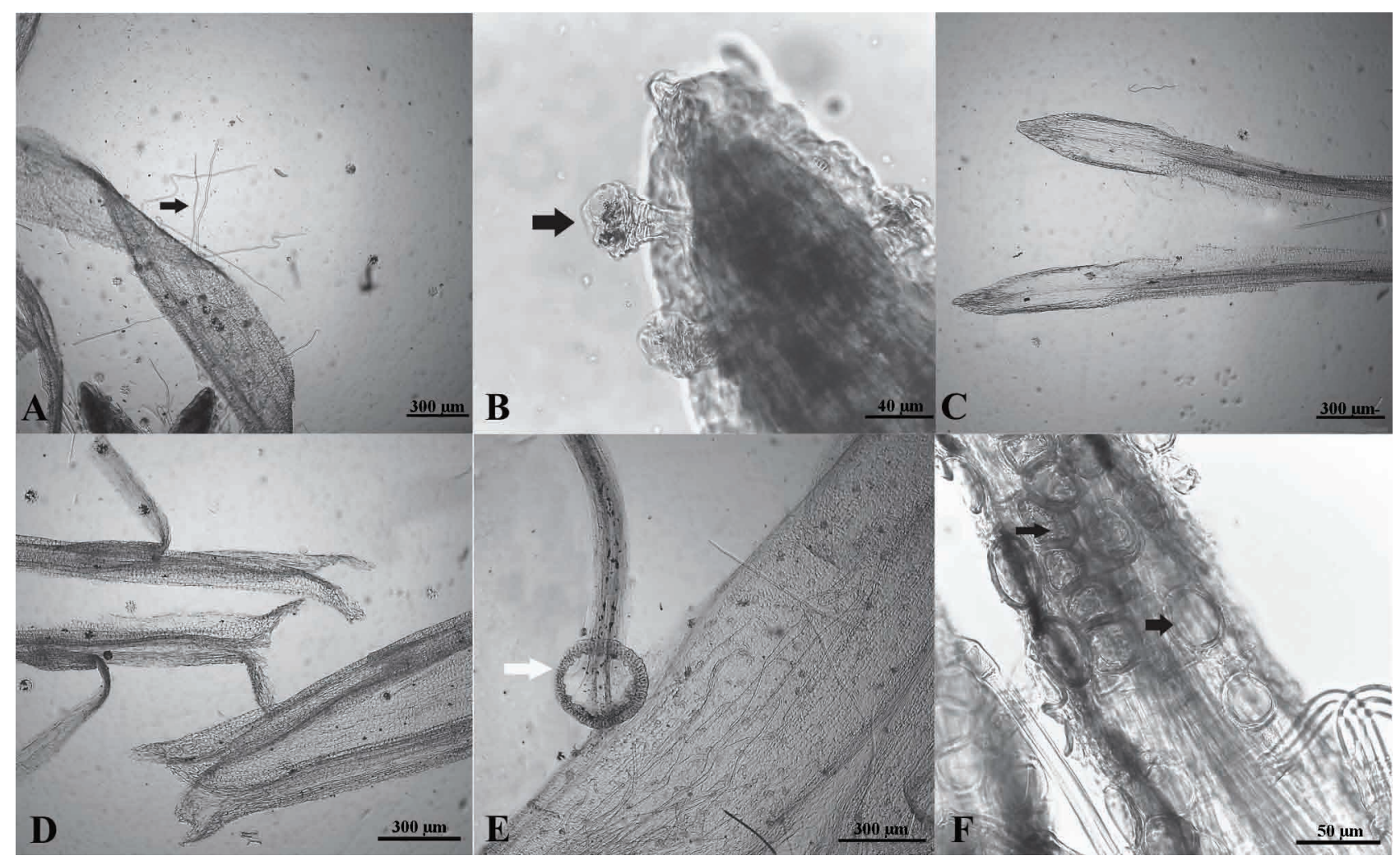

FIGURE 3. Floral microcharacters of Lepidaploa scintillans (LM): A: Corolla lobes with eglandular trichomes (black arrow). B: Corolla lobes with glandular trichomes (black arrow). C: Acute apical anther. D: Caudate basal anther. E: Basal style node (white arrow). F: Cypsela with idioblasts (black arrow).

\section{Acknowledgments}

We are grateful to Mirtha Liliana Gómez for the line drawing of the new species, and to Eduardo Damasceno Lozano who provided photographs accompanying this paper. Thanks to Maria Betiana Angulo for the critical reading of the manuscript. This work was supported by grants from the Consejo Nacional de Investigaciones Científicas y Técnicas (CONICET). 


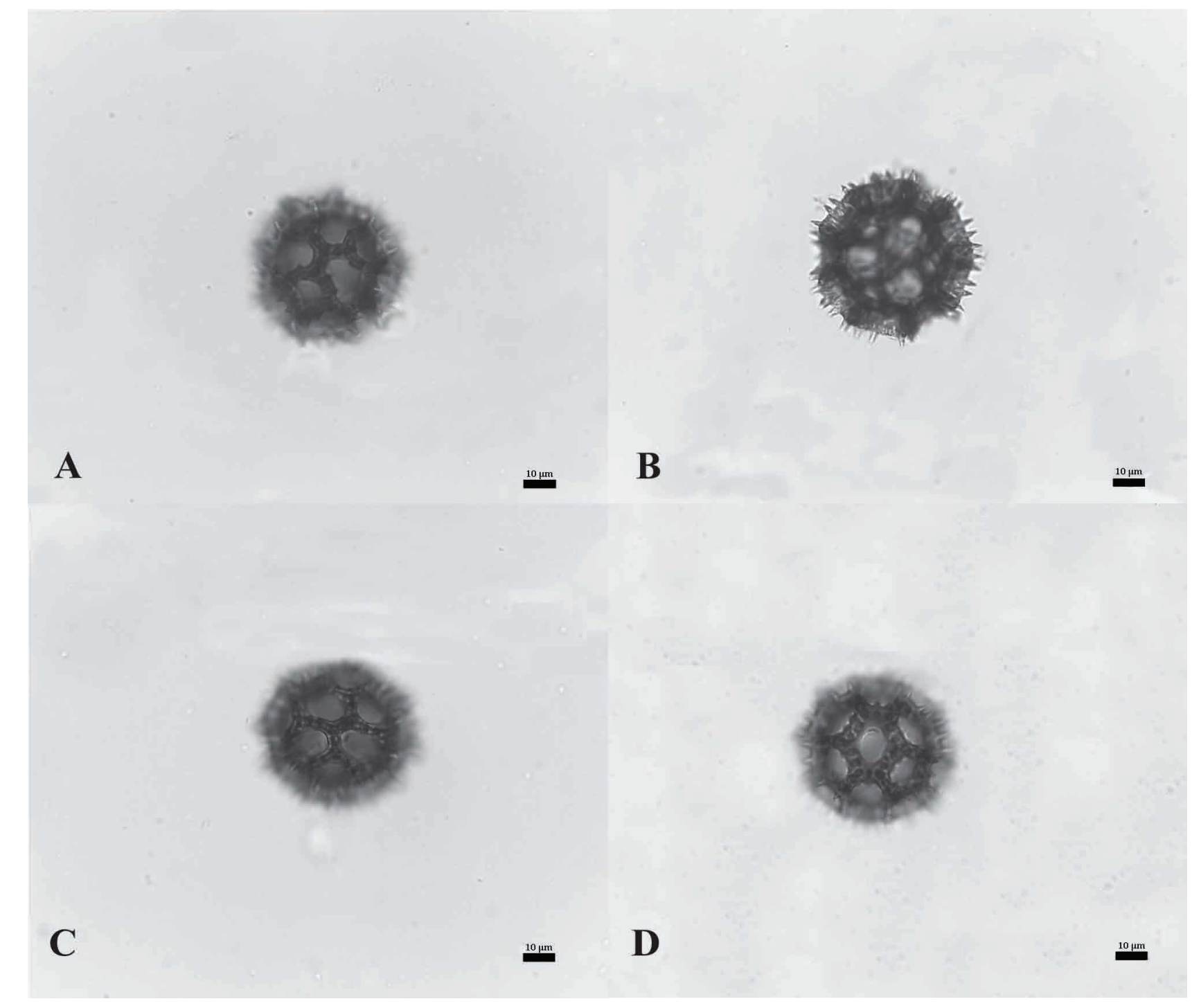

FIGURE 4. Pollen of Lepidaploa scintillans (LM): A: Polar view, high focus. B: Polar view, middle focus. C: Equatorial view, mesocolpium, high focus. D: Equatorial view, high focus. Scale bars $=10 \mu \mathrm{m}$.

TABLE 1. Diagnostic morphological characters of Lepidaploa scintillans and L. persericea.

\begin{tabular}{lll}
\hline & L. scintillans & L. persericea \\
\hline Blade & lanceolate & oblong-ovate \\
Leaf width & $0.1-0.3 \mathrm{~cm}$ & $1.2-3 \mathrm{~cm}$ \\
Leaf apex & acute to acuminate & acuminate \\
Leaf base & attenuate & rotund \\
Adaxial leaves & sericeous & pilose \\
Abaxial leaves & silver sericeous & yellowish sericeous \\
Capitulescence & $3.8-5.6$ cm long & ca. 26 cm long \\
Corolla lobes & eglandular and glandular trichomes & eglandular trichomes \\
Outer series of pappus & subpaleaceous & paleaceous \\
Distribution area & Minas Gerais (Brazil) & Bahia (Brazil) \\
\hline
\end{tabular}




\section{References}

Anderson, L.E. (1954) Hoyer's solution as a rapid mounting medium for bryophytes. The Bryologist 57: 242-247. http://dx.doi.org/10.2307/3240091

Angulo, M.B., Vega, A.J. \& Dematteis, M. (2012) Nuevas combinaciones en los géneros sudamericanos Lepidaploa y Lessingianthus (Vernonieae, Asteraceae). Gayana Botánica 69: 267-274. http://dx.doi.org/10.4067/S0717-66432012000200006

Baker, J.G. (1873) Stilpnopappus. In: Martius, C.F.P. \& Eichler, A.G. (Eds.) Flora brasiliensis. F. Fleischer, Lipsiae [Leipzig], pp. 134141.

Bremer, K. (1994) Asteraceae: cladistics and classification. Timber Press, Portland, 752 pp.

Cassini, A.H.G. (1817) Aperçu des generes noauveaux formés par M. Henri Cassini dans la familla des Synanthérés. Quatrième fascicule. Bulletin des Sciences de La Sociéte Philomatique de Paris 1817: 66-70.

Cassini, A.H.G. (1819) Suite du sixième mémoire sur la famille des Synanthérées, contenant les caractères des tribus. Journal de Physique, de Chimie, d'histoire Naturelle et des Arts 88: 189-204.

Cassini, A.H.G (1825) Oliganthe. Oliganthes. In: Cuvier, F.G. (Ed.) Dictionnaire des Sciences Naturelles, vol. 36. Strasbourg, F.G. Levrault, Paris, pp. 18-20.

Candolle, A.P. de (1836) Vernoniaceae. In: Candolle, A.P. de (Ed.) Prodromus systematis naturalis regni vegetablilis, vol. 5. Treuttel and Würtz, Paris, pp. 9-94.

Erdtman, G. (1966) Pollen morphology and plant taxonomy. Angiosperms: An introduction to Palynology. Hafner Publishing Company, New York, $557 \mathrm{pp}$.

Keeley, S.C. \& Robinson, H. (2009) Vernonieae. In: Funk, V.A., Susanna, A., Stuessy, T.F. \& Bayer, R.J. (Eds.) Systematics, evolution and biogeography of Compositae. International Association for Plant Taxonomy, Vienna, pp. 439-469.

Keeley, S.C. \& Jones, S.B. (1979) Distribution of the pollen types in Vernonia (Vernonieae: Asteraceae). Systematic Botany 4: 195-202. http://dx.doi.org/10.2307/2418418

King, R.M. \& Robinson, H. (1970) The new synantherology. Taxon 19: 6-11. http://dx.doi.org/10.2307/1217907

Marques, D. \& Dematteis, M. (2014) Lepidaploa (Cass.) Cass. In: Zuloaga, F.O., Belgrano, M.J. \& Anton, A.M. (Eds.) Flora Argentina, Flora Vascular de la República Argentina.vol. 7. Dicotyledoneae Asteraceae: Senecio a Vernonieae. IBODA CONICET, Argentina, pp. 243-249.

Punt, W., Hoen, P.P., Blackmore, S., Nilsson, S. \& Le Thomas, A. (2007) Glossary of pollen and spore terminology. Review of Palaeobotany Palynoly 143: 1-81. http://dx.doi.org/10.1016/j.revpalbo.2006.06.008

Robinson, H. (1988) Studies in the Lepidaploa complex (Vemonieae: Asteraceae), IV. The new genus Lessingianthus. Proceedings of the Biological Society of Washington 101: 929-951.

Robinson, H. (1990) Studies in the Lepidaploa Complex (Vernonieae: Asteraceae), VII. The genus Lepidaploa. Proceedings of the Biological Society of Washington 103: 952-958.

Robinson, H. (1999) Generic and subtribal classification of American Vernonieae. Smithsonian Contributions to Botany, Washington, D.C., 116 pp.

Schreber, J.C.D. von (1791) Genera plantarum, vol. 2. Sumptu Varrentrappii et Wenneri, Francofurti ad Moenum [Frankfurt am Main], $872 \mathrm{pp}$.

Via do Pico, G.M., Veja, A.J. \& Dematteis, M. (2016) Systematic consideration of floral microcharacters of the South American genus Chrysolaena (Vernonieae, Asteraceae). Systematics and Biodiversity 14: 224-243.

http://dx.doi.org/10.1080/14772000.2015.1134699 